\title{
ASSESSING VEGETATION AND FLUVIAL RESPONSES TO THE PALEOCENE-EOCENE THERMAL MAXIMUM IN THE HANNA BASIN (WYOMING, U.S.A.)
}

ELLEN D. CURRANO, University of Wyoming

BRADY Z. FOREMAN, Western Washington University

\section{INTRODUCTION}

The Paleocene-Eocene Thermal Maximum (PETM) represents the largest and most abrupt global warming event of the Cenozoic Era (Koch et al., 1992;

Zachos et al., 2001; McInerney \& Wing, 2011) and is viewed as one of the premier geologic analogs for modern, anthropogenic warming. Fifty-six million years ago, a massive pulse of isotopically-light carbon was introduced to the world's oceans and atmosphere, and Earth's mean global temperature increased by at least $5^{\circ} \mathrm{C}$ (Zachos et al., 2001; McInerney \& Wing, 2011). The event is recorded in numerous marine sediment cores whereas the continental record is limited to relatively few sites (McInerney \& Wing, 2011). This difference in geographic data coverage has resulted in reasonably well-constrained and understood consequences for marine biologic systems, ocean chemistry, and ocean temperatures (McInerney \& Wing, 2011), but a poorer understanding of the consequences for continental biologic and environmental conditions (Wing \& Currano, 2013). North America contains the most extensive record of climate change spanning the PETM, with carbon isotope records identifying the PETM event in five basins (Koch et al., 1992; Bowen \& Bowen, 2008; Clechenko et al., 2008; Foreman et al., 2012; Bataille et al., 2016). However, detailed sedimentologic descriptions of alluvial changes have only been performed at two locations (the Bighorn Basin, northwest Wyoming, and the Piceance Creek Basin, western Colorado) and paleobotanical changes documented at just one location (the Bighorn Basin) (Figure 1; Foreman et al., 2012; Wing and Currano, 2013; Kraus et al., 2015). With such limited

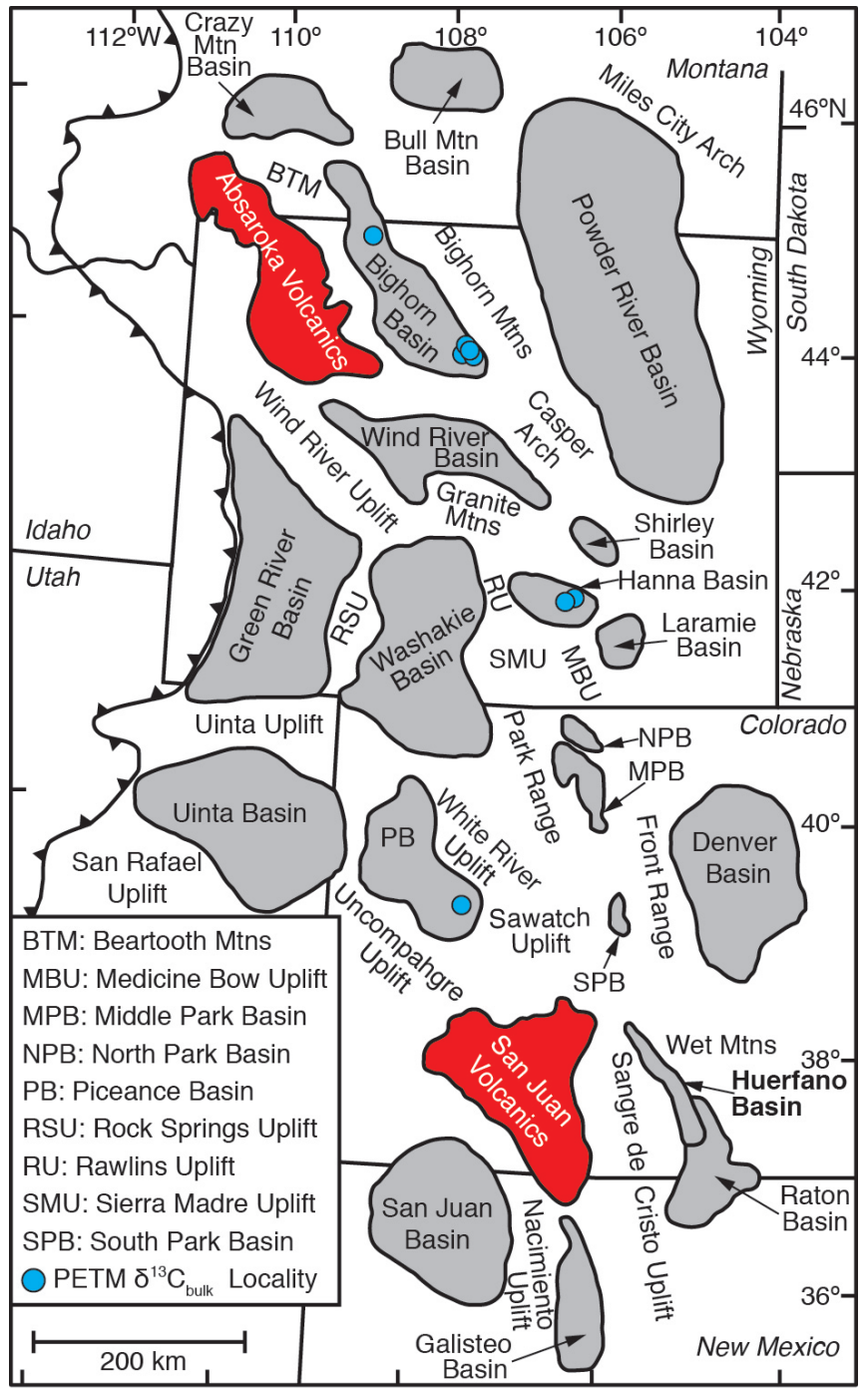

Figure 1. Map of Laramide basins with Paleogene sediments and surrounding uplifts. The negative carbon isotope excursion that marks the PETM has been previously identified in the Bighorn and Piceance Creek Basins. Data collected by the Keck Wyoming Project constrained the location of two additional PETM isotope excursions in the Hanna Basin. 


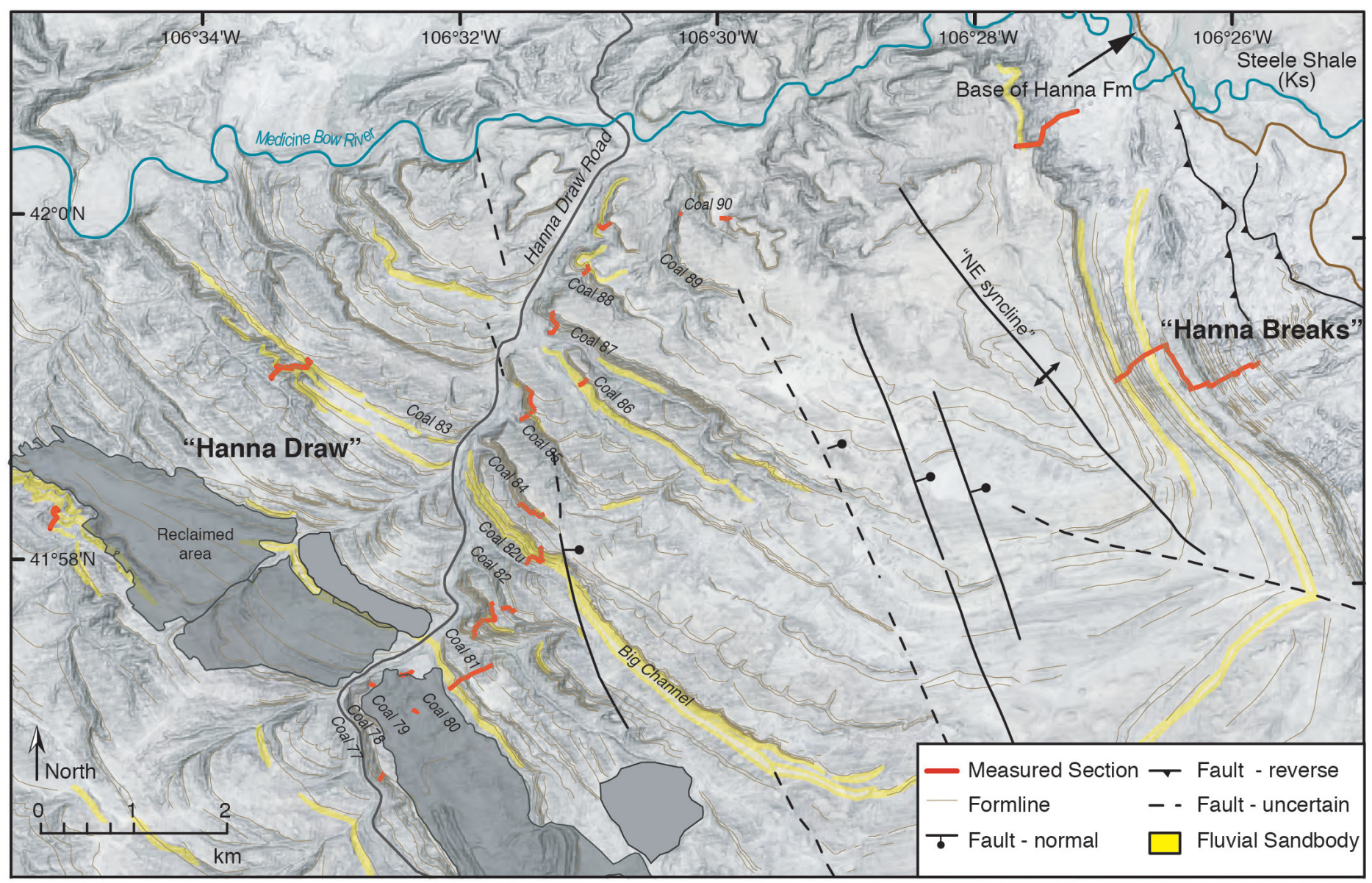

Figure 2. Location of the Hanna Draw and "The Breaks" sections within the Hanna Basin, modified from Dechesne et al. (in review). Large, laterally extensive fluvial sandstones are highlighted in Yellow, and the "Big Channel" sandstone occurs within the PETM interval. Section lines of Dechesne et al. (in review) are in red.

geographic coverage it is difficult to evaluate spatial gradients in response, and test fundamental climate hypotheses. This project expands this existing database to the Hanna Basin of south-central Wyoming, with the aim of evaluating spatial gradients in alluvial and biologic response to the PETM.

Broadly speaking, the terrestrial response to elevated carbon dioxide levels is expected to be variable to due topographic complexity and shifting atmospheric circulation patterns under different latitudinal thermal gradients. As such it is critical to develop additional continental locations where the temperature, hydrologic, and biologic changes are constrained. The Hanna Basin record is a particularly important complement to the record already collected in the Bighorn Basin because stratigraphic data suggest a difference in water availability between the two basins. Both the PETM interval and the entire early Eocene sequence preserved in the Willwood
Formation in the Bighorn Basin contain abundant red beds, indicative of well-drained soils and seasonal precipitation (Kraus and Riggins, 2007; Kraus et al., 2015). The Bighorn Basin records the consequences of an overall drier basin experiencing an abrupt global warming event. In contrast, the Hanna Basin sedimentary sequence remains drab-colored and coal-rich from bottom to top, suggesting that wet, swampy conditions prevailed through the PETM and early Eocene (Dechesne et al., in review). It records the consequences of a more humid basin experiencing an abrupt global warming event. Thus, comparisons of the Hanna and Bighorn basins will allow us to disentangle the roles of temperature and water availability in driving vegetation change and the fluvial response in a dominantly humid setting. This water availability difference is likely due to the location of the Hanna Basin, farther to the east and potentially more proximal to moisture sources as compared to the Bighorn Basin (Sewall \& Sloan, 
2006). The Laramide Orogeny created a complex topography within the Western Interior that strongly influenced water vapor transport paths (Sewall \& Sloan, 2006). In general, however, circulation models suggest the easternmost Laramide basins were wetter as moisture from the paleo-Gulf of Mexico moved north and westward. This resulted in semi-arid and dry conditions in the western and northernmost Laramide basins (Sewall \& Sloan, 2006).

\section{GEOLOGIC SETTING}

The Hanna Basin of south-central Wyoming is a Laramide style basin bounded by the Rawlins uplift to the west, Sweetwater Arch in the north, the Simpson Ridge anticline in the east, and the Medicine Bow and Sierra Madre Mountains in the south (regional basin/ mts figure). It is exceptional among the Laramide basins because of its high subsidence rate, extremely thick Cretaceous to Eocene sedimentary strata, and extensive coal deposits (Dobbin et al., 1929; Roberts and Kirschbaum, 1995; Wroblewski, 2003). The Paleocene-Eocene boundary is preserved in the Hanna Formation, which is over 2000 meters thick at the center of the basin (WOGCC, 2016; Gill et al., 1970; Wrobleski, 2003) and consists of conglomerates, sandstones, siltstones, carbonaceous shales, and coals. These deposits are interpreted as low gradient fluvial to paludal and lacustrine (Dobbin et al, 1929; Wrobelski, 2003; Lillegraven et al., 2004). The student projects targeted a specific set of extensive outcrops along the Hanna Draw Road and in "The Breaks" (Figure 2), which have been the focus of new geologic and paleontologic work by PI Currano, stratigrapher Marieke Dechesne of the USGS, and paleobotanist Regan Dunn of the Field Museum. The majority of research focuses on a 250-meter thick stratigraphic interval with pollen biostratigraphic constraints and initial bulk $\delta^{13} \mathrm{C}$ values that indicate the PETM is preserved.

\section{PROJECT GOALS}

Our team included six undergraduate researchers, two faculty members (Currano and Foreman), and two scientific collaborators (Dechesne and Dunn). The major projects goals include: (1) constraining the location of the PETM in the Hanna Basin using carbon

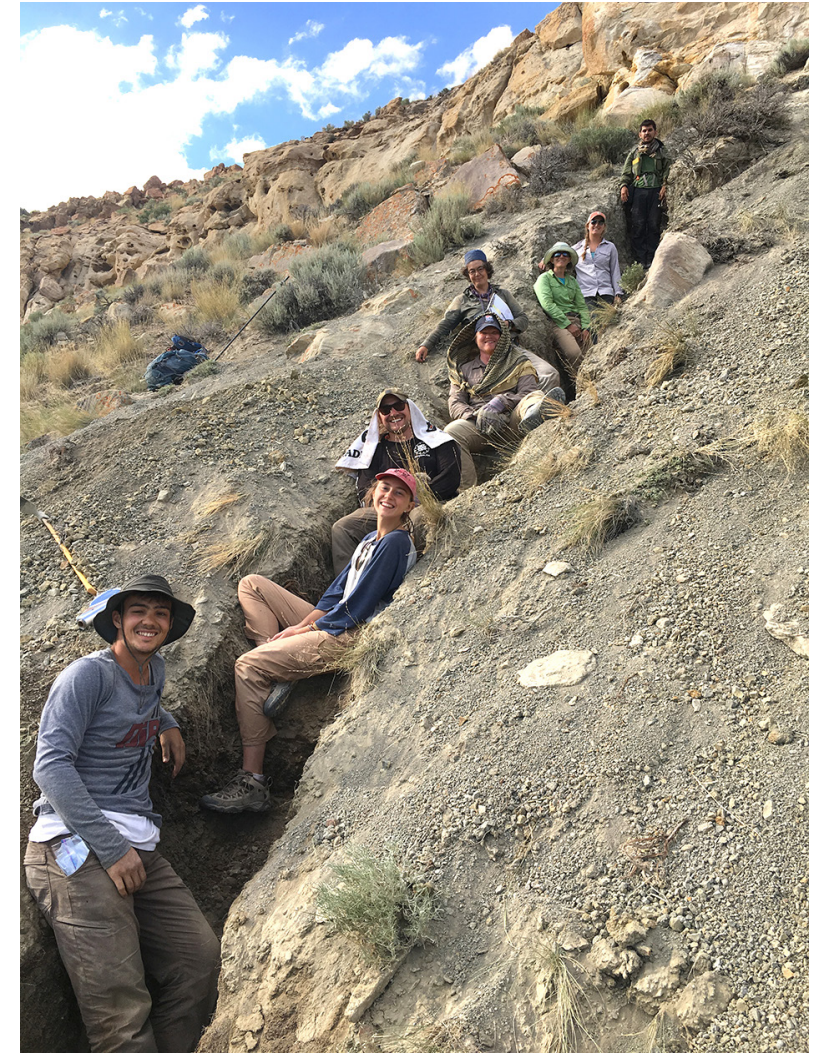

Figure 3. Members of the Keck Wyoming crew in the uppermost portion of the trench through the PETM in the Hanna Draw section. From bottom left, Xavier Nogueira, Christine Shonnard, Jake Polsak, Anthony Semeraro, Marieke Dechesne, Ellen Currano, Keifer Nace, and James Chisholm. Photograph by Brady Foreman.

isotope analyses; (2) characterizing and quantifying changes in fluvial and overbank deposition spanning the PETM; and (3) identifying and interpreting changes in vegetation cover spanning the PETM. The project goals were achieved by a combination of intensive field work and targeted lab work that focuses on stratigraphic section measuring, lithofacies analysis, a new highly-refined bulk organic carbon isotope stratigraphy, and application of new plant cuticle proxies for vegetation cover.

\section{RESEARCH PROJECTS}

The methodologies employed in this study combine foundational approaches to stratigraphy, sedimentology, and isotope geochemistry and new, cutting edge proxies for vegetation cover using the preserved leaf cuticles of ancient plants. All students were trained to measure and correlate stratigraphic sections, describe lithofacies, and prepare samples for bulk organic $\delta^{13} \mathrm{C}$ analyses. As a team, we trenched 
(Figure 3), measured, and described a stratigraphic section through the Paleocene-Eocene Thermal Maximum at Hanna Draw. In the lab, we worked together to prepare samples for geochemical analyses. Students then learned additional techniques related to their specific projects.

James Chisholm (CSU San Bernardino) analyzed all the carbon isotope data collected by the Keck Wyoming Project. His project identified where the PETM carbon isotope excursion (CIE) occurred within the Hanna Draw and The Breaks stratigraphic sections, compared the magnitude and duration of the CIE between our two sections, and assessed the causes of background "noise" related to baseline environmental conditions.

Xavier Nogueira (Temple University) and Anthony Semeraro (Western Washington University) examined fluvial systems during the late Paleocene, PETM, and Eocene. Nogueira collected samples from twentyfive sandstone bodies and performed point counts of minerals from thin sections. He tested whether compositional differences among samples were due to time, depositional environment, or flow direction and hypothesized about sediment sources. Semeraro measured paleoflow directions in modern and ancient channel systems to investigate fluctuations in stream flow during the PETM. He chose three modern meandering rivers and three modern braided systems, measured over 1000 flow directions from each, and calculated dispersion values (i.e. the variability in flow direction) for each river, showing that meandering rivers have more variability in flow direction than braided rivers. Last, he calculated dispersion values for channel systems in the late Paleocene, PETM, and early Eocene of the Hanna, Bighorn, and Piceance Creek. The Hanna flow direction measurements are his own.

Keifer Nace (Whitman College) and Jake Polsak (Western Washington University) documented vegetation structure using our new leaf area index (LAI = foliage area in $\mathrm{m}^{2} /$ ground area in $\mathrm{m}^{2}$ ) proxy (Dunn et al. 2018). This proxy utilizes the morphology of leaf epidermal cells, preserved as imprints on cuticles, to reconstruct canopy openness (Dunn et al. 2018). Dunn has already constructed a record of LAI across the PETM interval in both the
Hanna Draw sections documenting changes in LAI at the PETM, but context was needed to determine whether the change observed during the PETM was significant. In particular, large sheet sandstones occur during the PETM, making it unclear whether climatic or lithologic changes were responsible for the decrease in LAI observed during the PETM. Nace measured sections before and after the PETM that included large sandstone units and reconstructed LAI throughout each section. She then compared her results with the Dunn's PETM record. Polsak assessed temporal and spatial variability in LAI within the early Eocene by measuring four contemporaneous sections and reconstructing LAI at high temporal and spatial resolution in each section. He then examined variability in LAI across time, space, and lithology.

Christine Shonnard (Beloit College) compared cyclic overbank deposition within the Hanna Formation of south-central Wyoming and Willwood Formation of northwest Wyoming. Both formations include repetitive packages of fine-grained deposits and sandstones, although the composition of the fine-grained deposits varies between formations, likely driven by drainage within the basin. The Hanna Formation contains organic-rich silts and shales, whereas the Willwood Formation is dominated by redbeds. Shonnard described lithological changes at high resolution in two sections in The Breaks, performed geochemical analyses, and reconstructed paleoclimate. She compared her sedimentary cycles with those from the Willwood Formation.

\section{ACKNOWLEDGEMENTS}

This material is based upon work supported by the Keck Geology Consortium and the National Science Foundation under Grant No. 1659322, as well as NSF grant EAR 145031 to Ellen Currano. We gratefully acknowledge our longtime Hanna Basin collaborators, Regan Dunn and Marieke Dechesne, for sharing their time and expertise with the Keck students. We thank the Palm family and Q Creek Ranch for land access and Mark Clementz for use of his lab.

\section{REFERENCES}

Bataille, C.P., Watford, D., Ruegg, S., Lowe, A., 
Bowen, G.J. 2016. Chemostratigraphic age model for the Tornillo Group: A possible link between fluvial stratigraphy and climate. Palaeogeography, Palaeoclimatology, Palaeoecology 457: 277-289.

Bowen, G.J., Bowen, B.B. 2008. Mechanisms of PETM global change constrained by a new record from central Utah. Geology 36: 379-382.

Clechenko, E.R., Kelly, D.C., Harrington, G.J., Stiles, C.A. 2008. Terrestrial records of a regional weathering profile at the Paleocene-Eocene boundary in the Williston Basin of North Dakota. GSA Bulletin 119: 428-442.

Dechesne, M., Currano, E.D., Dunn, R.E., Higgins, P., Hartman, J., Chamberlain, K. in review. Climatic and tectonic responses of the fluvial to paludal strata of the Hanna Formation around the Paleocene-Eocene Boundary, Hanna Basin, Wyoming.

Dobbin, C.E., Bowen, C.F., Hoots, H.W. 1929. Geology and coal and oil resources of the Hanna and Carbons basins, Carbon County, Wyoming. U.S. Geological Survey Bulletin 804: 88.

Dunn, R.E., Currano, E.D., Dechesne, M., \& Foreman, B.Z. (2018). Forest canopy response to greenhouse warming at the Paleocene-Eocene Thermal Maximum. GSA Annual Meeting, Indianapolis.

Foreman, B.Z., Heller, P.L., Clementz, M.T. 2012. Fluvial response to abrupt global warming at the Palaeocene/Eocene boundary. Nature 491: 92-95.

Koch, P.L., Zachos, J.C., Gingerich, P.D. 1992. Correlation between isotope records in marine and continental carbon reservoirs near the Palaeocene/Eocene boundary. Nature 358: 319322.

Kraus, M.J., Riggins, S., 2007. Transient drying during the Paleocene-Eocene Thermal Maximum (PETM): analysis of paleosols in the Bighorn Basin, Wyoming. Palaeogeography, Palaeoclimatology, Palaeoecology 245: 444-461.

Kraus, M.J., Woody, D.T., Smith, J.J., Dukic, V.,
2015. Alluvial response to the Paleocene-Eocene Thermal Maximum climatic event, Polecat Bench, Wyoming (U.S.A.). Palaeogeography, Palaeoclimatology, Palaeoecology 435: 177-192.

Lillegraven, J. A., Snoke, A. W., McKenna, M. C. 2004. Tectonic and paleogeographic implications of late Laramide geologic history in the northeastern corner of Wyoming's Hanna Basin. Rocky Mountain Geology 39: 7-64.

Gill, J. R., Merewether, E. A., and Cobban, W. A., 1970, Stratigraphy and nomenclature of some Upper Cretaceous and lower Tertiary rocks in south-central Wyoming. U.S. Geological Survey Professional Paper 667, 53 p.

Roberts, L.N.R., and Kirschbaum, M.A., 1995, Paleogeography of the Late Cretaceous of the Western Interior of middle North America-Coal distribution and sediment accumulation. U.S. Geological Survey Professional Paper 1561, 155 p.

Sewall, J.O., Sloan, L.C. 2006. Come a little bit closer: A high-resolution climate study of the early Paleogene Laramide foreland. Geology 34: 81-84.

WOGCC, Wyoming Oil and Gas Conservation Commission well log database: http://wogec.wyo. gov/ (July 2016).

Wing, S.L., Currano, E.D., 2013. Plant response to a global greenhouse event 56 million years ago. American Journal of Botany 100: 1234-1254.

Wroblewski, A. F.-J., 2003, The role of the Hanna Basin in revised paleogeographic reconstructions of the Western Interior Sea during the Cretaceous-Tertiary transition, in Horn, M. S., ed., Wyoming Geological Association Guidebook, 2002 Field Conference "Wyoming Basins" and 2003 Field Conference, p. 17-40.

Zachos, J.C., Pagani, M., Sloan, L., Thomas, E., Billups, K., 2001. Trends, rhythms, and aberrations in global climate $65 \mathrm{Ma}$ to present. Science 292: 686-693. 